\title{
Effect of Black Ginseng on Memory Improvement in the Amnesic Mice Induced by Scopolamine
}

\author{
Mi-Ra Lee ${ }^{1}$, Beom-Sik Yun ${ }^{1}$, Lei Liu ${ }^{1}$, Dong-Liang Zhang ${ }^{1}$, Zhen Wang ${ }^{1}$, Chun-Ling Wang ${ }^{1}$, \\ Li-Juan $\mathbf{G u}^{2}$, Chun-Yan Wang ${ }^{2}$, Eun-Kyung $\mathrm{Mo}^{2}$ and Chang-keun Sung ${ }^{1}$ * \\ ${ }^{1}$ Department of Food Science and Technology, Chungnam National University, Daejeon 305-764, Korea \\ ${ }^{2}$ Daeduck Bio Research Institute, Daejeon, 305-764
}

(Received January 13, 2010; Revised February 3, 2010; Accepted February 6, 2010)

\begin{abstract}
This study compared the effects of black, white, and red ginseng extracts (WGE, RGE, BGE, $200 \mathrm{mg} / \mathrm{kg}$, p.o.) on learning and memory deficits associated with scopolamine treatment (SCOP, $2 \mathrm{mg} / \mathrm{kg}$, i.p.). Tacrine (THA, $10 \mathrm{mg} / \mathrm{kg}$, p.o.) was used as a positive control. Ginseng significantly reversed SCOP-induced memory impairment in the passiveavoidance test and also reduced escape latency in training trials of the Morris water maze test. The increased acetylcholinesterase (AChE) activity produced by SCOP was significantly inhibited by WGE and RGE $(p<0.001)$. SCOP administration had no effect on choline acetyltransferase (ChAT) activity, but RGE and BGE significantly increased ChAT activity $(p<0.05)$. SCOP administration increased oxidative damage in the brain. Treatment of amnesic mice with ginseng extracts decreased malondialdehyde (MDA) levels and restored superoxide dismutase (SOD) and catalase (CAT) activity to control levels. These results suggest that black ginseng enhances cognitive activity by regulation of cholinergic enzymes and antioxidant systems.
\end{abstract}

Key words : back ginseng, scopolamine, acetylcholinesterase, choline acetyltransferase

\section{INTRODUCTION}

Alzheimer's disease produces significant cognitive impairment that arises from dysfunction in numerous neurotransmitter systems, particularly from damage to cholinergic neurons known to play an important role in learning and memory [1]. Cholinergic depletion is used as a marker of neurological pathology and is associated with memory loss and the severity of Alzheimer's disease symptoms [2]. Scopolamine (SCOP) is a muscarinic cholinergic receptor antagonist that causes learning and memory impairments in humans and animals similar to those observed in Alzheimer's patients. It is also widely used in animal models to evaluate the effects of potential anti-dementia drugs $[3,4]$.

Ginsenosides, the main active constituents in ginseng, are reported to have pharmacological effects on the central nervous system (CNS), as well as possessing anti-cancer, anti-diabetic, anti-oxidative, anti-ageing, and immunestrengthening effects $[5,6]$. The discovery of the effects

\footnotetext{
* Corresponding author. E-mail: kchsung@cnu.ac.kr Phone: +82-42-821-6722, Fax: +82-42-822-2287
}

of specific ginsenosides has led attempt structural conversion of the specific ginsenoside. For example, nine repeated cycles of steaming, commonly used for Rehmannia root preparation, have been applied to ginseng to make black ginseng, which can increased ginsenoside $\mathrm{Rg}_{3}$ in red ginseng. Ginsenoside $\mathrm{Rg}_{3}$ is known for its neuroprotective, anti-anemic, and analgesic effects [7, 8] and is being massproduced in China, where has been successfully commercialized as anti-cancer treatment agent [9].

We compared the effects of black ginseng, white ginseng, and red ginseng on SCOP-induced memory impairment in mice using the passive-avoidance test and Morris water maze. We also investigated ginseng's antioxidant activity, effects on acetylcholinesterase (AChE) and choline acetyltransferase (ChAT) activity, enzymes responsible for acetylcholine (ACh) degradation and synthesis, and effects on SCOP-induce oxidative brain damage.

\section{MATERIALS AND METHODS}

\section{Ginseng extract preparation}

White ginseng and red ginseng made from 4-year-old 
ginseng were purchased from a local ginseng center (Geumsan, Korea). To prepare black ginseng, ginseng was subjected to nine cycles of steaming at $98^{\circ} \mathrm{C}$ for $3 \mathrm{hr}$ followed by drying at $65^{\circ} \mathrm{C}$ for $18 \mathrm{hr}$. To prepare the extract, ginseng was crushed into powder and ultrasonicated three times in 10 volumes of $20 \%$ ethanol at $50^{\circ} \mathrm{C}$ for $1 \mathrm{hr}$, then was filtered, lyophilized. The extraction yield of white ginseng, red ginseng, and black ginseng was $36.02 \%, 48.44 \%$, and $54.50 \%$, respectively.

\section{Saponin analysis}

Saponin determination was analyzed as described by Shi et al. [10], with the following modifications. To extract saponin, $1 \mathrm{~g}$ of white ginseng, red ginseng, or black ginseng was added to $20 \mathrm{ml}$ of $20 \%$ ethanol and ultrasonicated three times at $50^{\circ} \mathrm{C}$ for $1 \mathrm{hr}(60 \mathrm{kHz}$, heat power $330 \mathrm{~W}$ ). The extract was retrieved and concentrated in vасио. For saponin analysis, the sample was dissolved in $20 \mathrm{ml}$ of distilled water and transferred to a separatory funnel containing the same volume of ethyl ether. Lipid components in the sample were removed by extracting with ethyl ether three times. The sample was further extracted with $20 \mathrm{ml}$ of water-saturated butanol three times, after which the water-saturated butanol layer was concentrated in vacuo. The samples were then dissolved in $10 \mathrm{ml}$ of $80 \%$ methanol and filtered through a $0.45-\mu \mathrm{m}$ membrane filter. Saponin levels were quantified by HPLC analysis (SPD 20A, SIMADZU, Kyoto, Japan) using an ACE $5 \mathrm{C}_{18}$ column $(250 \times 0.4 \mathrm{~mm}, 5 \mu \mathrm{m})$ and UV detector $(203 \mathrm{~nm})$. The mobile phase was a gradient of water and acetonitrile. To elute saponin, the acetonitrile concentration was adjusted as follows: $0-30 \mathrm{~min}, 20 \%$; 30-60 min, 20-45\%; 60-78 min, 45-75\% ; 78-80 min, 75-80\%; $80-100 \mathrm{~min}, 80-100 \%$. After injecting $10 \mu \mathrm{L}$ of sample, the mobile-phase flow rate was adjusted to $1 \mathrm{~mL} / \mathrm{min}$. As controls, ginsenoside standards $\left(\mathrm{Rg}_{1}, \mathrm{Re}, \mathrm{Rf}, \mathrm{Rb}_{1}, \mathrm{Rc}, \mathrm{Rb}_{2}\right.$, $\mathrm{Rd}, 20(\mathrm{~S})-\mathrm{Rg}_{3}, 20(\mathrm{R})-\mathrm{Rg}_{3}$ ) with $>98 \%$ purity were purchased from Hongjiu Biotech Co., Ltd. (Jilin, China).

\section{Animals}

ICR mice, 8 weeks old and weighing 25-30 g, were purchased from DaeHan Biolink Co. Ltd. (Eumseong-gun, Korea) and acclimatized for 1 week at $23 \pm 2^{\circ} \mathrm{C}, 55 \pm 5 \%$ humidity, with a 12:12-hr dark:light cycle. Mice were fed water and food ad libitum. Animals were cared for under the guidelines of the United States National Institutes of Health (No. 85-23, revised 1985), and all experiments were approved by Chungnam National University animal experiments ethics committee.

\section{Administration of drugs}

Scopolomine (Sigma, St. Louis, MO, USA) was injected to produce learning and memory deficits $(2 \mathrm{mg} / \mathrm{kg}$, i.p.), and tacrine, a cholinesterase inhibitor was used as a positive control (10 mg/kg, p.o.). Ginseng extract (200 mg/kg, p.o.) was administered as described by Qiao et al. [11] and Lee et al. [12]. Ginseng extract and THA were administered $1 \mathrm{hr}$ before behavioral experiments, and SCOP was administered 30 min before to induce memory impairments. All drugs were dissolved in saline, and the control group received equal volumes of saline.

\section{Passive-avoidance test}

Passive avoidance test was carried out in identical illuminated and non-illuminated boxes (Jungdo Bio \& Plant Co. Ltd, Seoul, Korea). The illuminated compartment $(20 \times 20 \times 20 \mathrm{~cm})$ contained a $100 \mathrm{~W}$ bulb. The non-illuminated compartment had a floor $(20 \times 20 \times 20 \mathrm{~cm})$ composed of $2 \mathrm{~mm}$ stainless steel rods spaced $1 \mathrm{~cm}$ apart. These two compartments were separated by a guillotine door $(5 \times 5 \mathrm{~cm})$. For the acquisition trial, mice were initially placed in the illuminated compartment and the door between the two compartments was opened $10 \mathrm{sec}$ later. When mice entered the dark compartment, the door automatically closed and an electrical foot shock $(0.5 \mathrm{~mA})$ of $3 \mathrm{sec}$ duration was delivered through the stainless steel rods (acquisition trial). Twenty-four hours after the acquisition trial, mice were again placed in the illuminated compartment to test retention (retention trial). The time taken for a mouse to enter the dark compartment after the door opened was defined as latency. If a mouse did not enter the dark compartment within $300 \mathrm{sec}$, it was assumed that the mouse had remembered the single 'acquisition' trial experience.

\section{Morris water maze test}

To evaluate spatial learning, the Morris water maze test was used, as described by Morris [13]. A round tub (diameter $90 \mathrm{~cm}$, height $50 \mathrm{~cm})$ was filled with water $\left(23 \pm 2^{\circ} \mathrm{C}\right)$ to a height of $30 \mathrm{~cm}$, and a clear round platform $(10 \mathrm{~cm}$ in diameter) was placed in one location $1 \mathrm{~cm}$ below the water level. Before the experiment, white dye was dispersed evenly throughout the water so that platform was not visible. On the first test day, the mouse was allowed to swim freely for $60 \mathrm{sec}$ with no platform in the tub. For the next 4 days, the mouse was trained three times per day with different sites in the tub. Once the mouse located the platform, it was allowed to stay on it for $10 \mathrm{sec}$. If the mouse did not find the platform within $120 \mathrm{sec}$, it was placed on the platform for $10 \mathrm{sec}$. The time interval between 
trial sessions was $20 \mathrm{~min}$.

On day 5 , mice were individually subjected to a probe trial session in which the platform was removed and the amount of time required for the mouse to find the platform location was measured to assess working memory.

\section{Biochemical analysis}

Following the water maze test, mice were sacrificed, and their brains removed and homogenized in 10 volumes of homogenization buffer $(12.5 \mathrm{mM}$ sodium phosphate buffer $\mathrm{pH}$ 7.0, $400 \mathrm{mM} \mathrm{NaCl}$ ) followed by centrifugation at $1,000 \mathrm{~g}$ for $15 \mathrm{~min}$. Subsequently, the supernatant was used to determine acetylcholinesterase (AChE) activity using a modified version of the method of Ellman [14] with acetylcholine iodide as a substrate. Malondialdehyde (MDA) content in the brain was determined using the thiobarbituric acid-reactive substances (TBARS) method as described by Uchiyama et al. [15]. Choline acetyltransferase (ChAT), superoxide dismutase (SOD), catalase (CAT), and total antioxidant capacity (TAOC) were determined using kits (Nianjing Jiancheng Bioengineering Institute, Nanjing, PR, China). Total protein was determined using the Bradford method [16].

\section{Statistical analysis}

All data were analyzed using the SPSS statistical software package, version 15.0. Differences between groups were analyzed using ANOVA and Duncan's multiple range test. $P<0.05$ was considered significant.

\section{RESULTS AND DISCUSSION}

\section{Saponin content in ginseng extract}

Table 1 and Fig. 1 showed the amounts of nine ginse- nosides analyzed by HPLC and chromatograms of the ginseng extracts used in this study. The total amount of ginsenosides was $49.59 \pm 0.54 \mathrm{mg}$ in white ginseng extract, $38.52 \pm 0.69$ in red ginseng extract, and $20.65 \pm$ $0.50 \mathrm{mg}$ in black ginseng extract, indicating that the white ginseng extract had the highest ginsenoside content.

Ginsenoside $\mathrm{Rg}_{3}$ was not detected in white ginseng extract, whereas $1.40 \pm 0.06 \mathrm{mg}$ was found in red ginseng and $12.80 \pm 0.23 \mathrm{mg}$ in black ginseng. Ginsenoside $\mathrm{Rg}_{3}$ comprised $62 \%$ of the total ginsenosides content in black ginseng. $\mathrm{Rg}_{1}$ and $\mathrm{Rb}_{1}$ are known to be involved in learning and memory. The total amount of $\operatorname{Rg}_{1}$ and $\mathrm{Rb}_{1}$ was $22.15 \pm 0.24 \mathrm{mg}$ in white ginseng and $16.38 \pm 0.24 \mathrm{mg}$ in red ginseng. In black ginseng, no $\operatorname{Rg}_{1}$ was detected, and we found $2.21 \pm 0.07 \mathrm{mg}$ of $\mathrm{Rb}_{1}$, a significantly lower amount than in the other extracts. During the heating process used to process black ginseng, protopanaxadiol-type saponins including $\mathrm{Rb}_{1}, \mathrm{Rg}_{1}, \mathrm{Rc}$, and $\mathrm{Rd}$ are converted to ginsenoside $\mathrm{Rg}_{3}$ by hydrolysis of a sugar residue at $\mathrm{C}-20$ or isomerization of a hydroxyl $(\mathrm{OH})$ group at C-20 [17]. Additionally, the chromatogram of black ginseng extract revealed that approximately 10 ginsenosides were detected after 60 min HPLC retention time (Fig. 1), demonstrating that a large amount could be generated through the heating and steaming of ginseng.

\section{Passive-avoidance test}

The passive-avoidance test was used to examine whether a single administration of ginseng could protect against SCOP-induced memory impairment. Step-through latency following SCOP treatment was $17.48 \pm 7.50 \mathrm{sec}$, significantly shorter than in the saline treated control group $(252.00 \pm 106.03 \mathrm{sec} ; p<0.001$, Fig. 2).

The THA-treated positive control group showed a sig-

Table 1. Ginsenoside contents in Korean ginseng extracts

\begin{tabular}{cccc}
\hline \hline Ginsenoside $(\mathrm{mg} / \mathrm{g} \text { extract })^{1)}$ & WGE & RGE & BGE \\
\hline $\mathrm{Rg}_{1}$ & $9.27 \pm 0.13$ & $6.94 \pm 0.09$ & ND \\
$\mathrm{Re}$ & $8.29 \pm 0.08$ & $5.07 \pm 0.06$ & $\mathrm{ND}$ \\
$\mathrm{Rf}$ & $2.17 \pm 0.07$ & $1.54 \pm 0.12$ & $0.81 \pm 0.02$ \\
$\mathrm{Rb}_{1}$ & $12.88 \pm 0.11$ & $9.44 \pm 0.15$ & $2.21 \pm 0.07$ \\
$\mathrm{Rc}$ & $9.90 \pm 0.04$ & $7.89 \pm 0.10$ & $3.26 \pm 0.11$ \\
$\mathrm{Rb}_{2}$ & $5.22 \pm 0.06$ & $4.36 \pm 0.07$ & $1.16 \pm 0.06$ \\
$\mathrm{Rd}$ & $1.86 \pm 0.05$ & $1.86 \pm 0.04$ & $0.40 \pm 0.01$ \\
$\mathrm{Rg}_{3}(\mathrm{~S})$ & $\mathrm{ND}$ & $0.66 \pm 0.02$ & $7.48 \pm 0.21$ \\
$\mathrm{Rg}_{3}(\mathrm{R})$ & $\mathrm{ND}$ & $0.74 \pm 0.04$ & $5.32 \pm 0.02$ \\
\hline $\mathrm{Total}$ & $49.59 \pm 0.54$ & $38.52 \pm 0.69$ & $20.65 \pm 0.50$ \\
\hline
\end{tabular}

\footnotetext{
${ }^{1)}$ Values were expressed as the mean \pm SD $(n=3)$. ND : not detected.

${ }^{2}$ WGE: white ginseng extract, RGE : red ginseng extract, BGE : black ginseng extract
} 

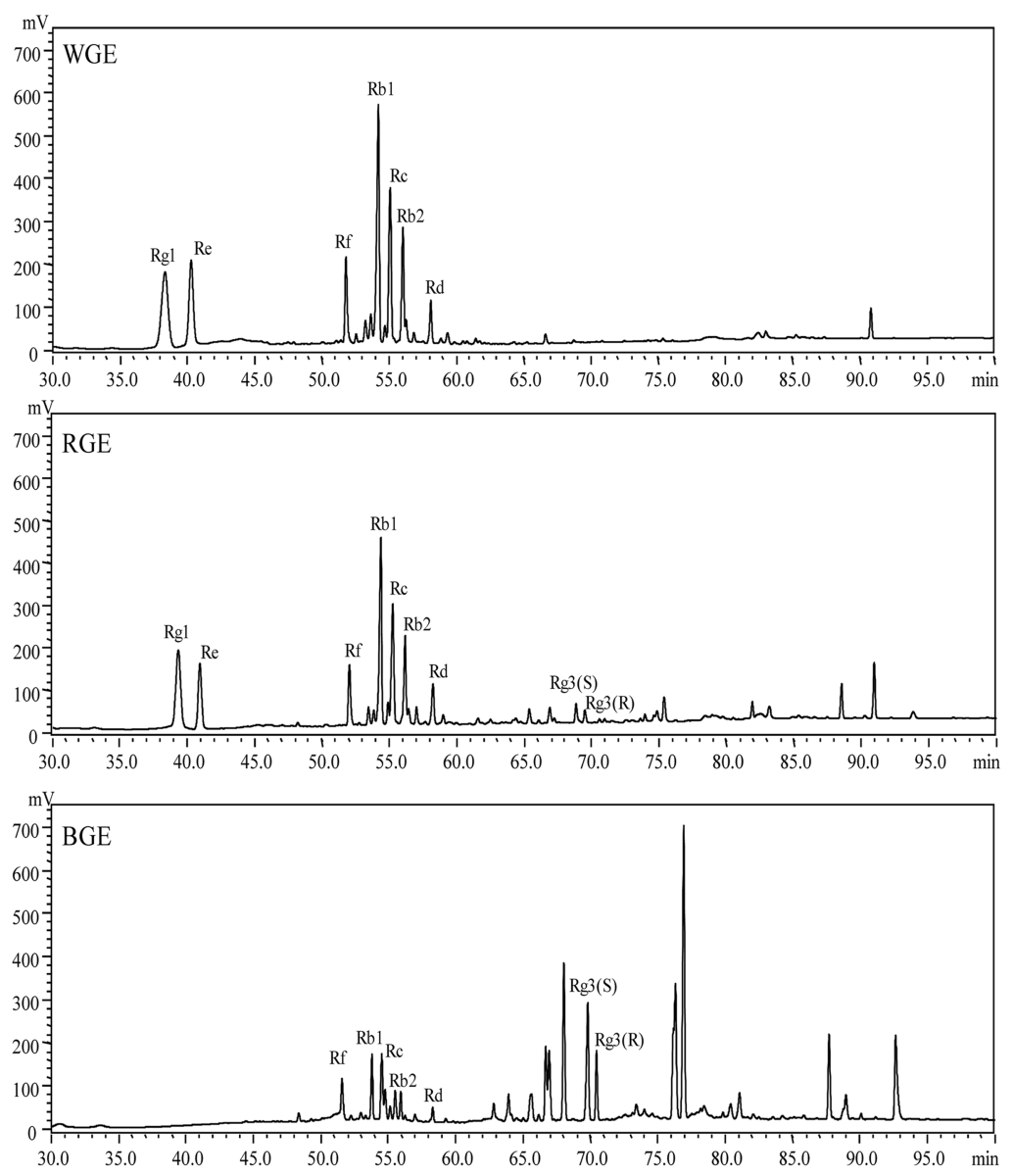

Fig. 1. HPLC-UV chromatograms of ginsenosides in Korean ginseng extracts. White ginseng extract (WGE), red ginseng extract (RGE), black ginseng extract (BGE).

nificantly increased step-through latency $(p<0.05)$, demonstrating anti-amnesic effects. The ginseng extract-treated groups also showed significantly increased step-through latency $(p<0.01)$, and a higher efficacy than THA. However, no drugs had an effect on latency time in the acquisition trial.

\section{Morris water maze test}

We used the water maze to examine the effect of ginseng extracts on spatial learning and memory in SCOPtreated amnesic mice. The escape latency of the SCOPtreated group was significantly higher than that of the control group during training sessions, demonstrating that long-term memory was impaired by SCOP treatment (Fig. 3A). THA and ginseng extract treatment reversed the effects of SCOP, and similar escape latencies were observed in THA- and ginseng-treated groups as in controls, even after the third day of training. On day 4, the escape latency of the THA and ginseng group were significantly lower than that of the SCOP group. On day 5, the platform was removed, and the probe test was conducted. In the probe test, ginseng extract treatment lowered escape latency of SCOP-treated mice to control levels, demonstrating that 4 days of ginseng extract administration enhanced spatial learning and memory. In contrast, the group treated with SCOP alone showed significantly increased escape latency compared to the control group $(p<0.001)$.

\section{Activities of cholinergic marker proteins}

To investigate the underlying mechanisms of the memory-enhancing effects of ginseng extract, we measured the activity of cholinergic marker enzymes including ChAT and AChE (Table 2). SCOP impairs learning and memory by inhibition of the muscarinic cholinergic receptor, and it has been used in animal models of diseases with memory impairment such as Alzheimer's and other degenerative neurological diseases [18]. ACh is a key neurotransmitter in learning and memory, and its activity is terminated by hydrolysis into acetate and choline by AChE [19]. The 


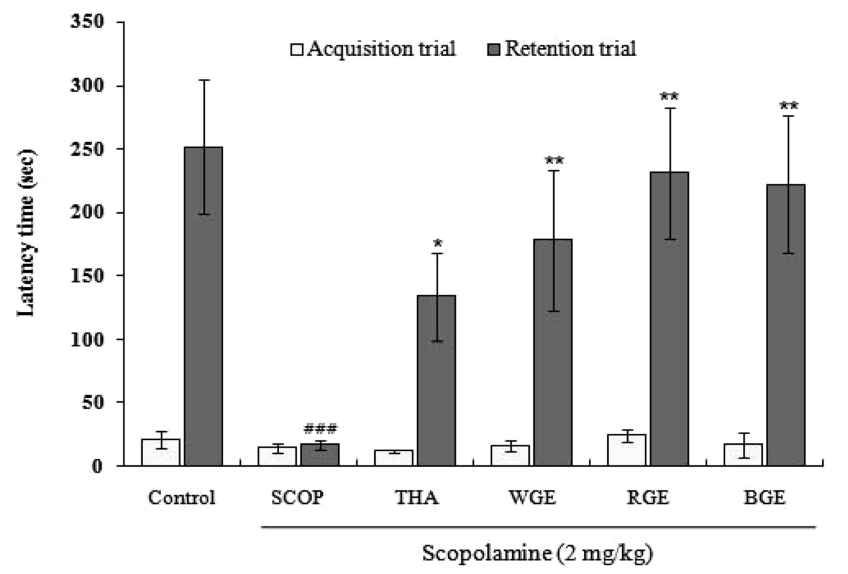

Fig. 2. Effect of a single administration of Korean ginseng extracts on SCOP-induced memory deficits in the passive-avoidance task. Control (equal volume of $0.9 \%$ saline), THA (tacrine, $10 \mathrm{mg} / \mathrm{kg}$, p.o.), WGE, RGE, or BGE (white, red, and black ginseng extract, $200 \mathrm{mg} / \mathrm{kg}$, p.o., respectively) were administered to mice $60 \mathrm{~min}$ before the acquisition trial. Memory impairment was induced by SCOP treatment (scopolamine, $2 \mathrm{mg} / \mathrm{kg}$, i.p.). Acquisition trials were carried out $30 \mathrm{~min}$ after SCOP administration. Retention trials were carried out $24 \mathrm{~h}$ after the acquisition trials. Results are expressed as means $\pm \mathrm{SD}(\mathrm{n}=10) . * p<0.05, * * * p<0.001$ versus SCOP

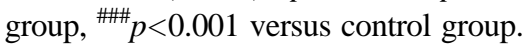

SCOP-treated group had the highest AChE activity (9.04 $\pm 1.03 \mathrm{U} / \mathrm{mg}$ protein), as reported previously by Yamada et al. [20]. AChE activity in the THA-treated group was $7.72 \pm 0.38 \mathrm{U} / \mathrm{mg}$ protein, which was $20 \%$ lower than in the group treated with SCOP alone $(p<0.05)$. In contrast, treatment with white and red ginseng extract resulted in AChE activity of $5.18 \pm 0.85 \mathrm{U} / \mathrm{mg}$ protein and $5.69 \pm$ $0.85 \mathrm{U} / \mathrm{mg}$ protein, respectively, which was $45 \%$ and $40 \%$ lower, respectively, than in the group treated with SCOP alone $(p<0.001)$. Additionally, black ginseng extract lowered AChE activity to $8.63 \pm 0.48 \mathrm{U} / \mathrm{mg}$ protein, a lesser reduction than white and red ginseng but similar to the control group. ChAT is the enzyme responsible for ACh synthesis in the CNS and was not affected by SCOP treatment, consistent with previous reports [21]. However, red and black ginseng treatment increased ChAT activity to $1.96 \pm 0.13 \mathrm{U} / \mathrm{mg}$ protein and $2.02 \pm 0.18 \mathrm{U} / \mathrm{mg}$ protein, respectively, values that were significantly higher than in the control group $(1.75 \pm 0.13 \mathrm{U} / \mathrm{mg}$ protein; $p<0.05)$.

Table 2 showed that the three types of ginseng extract attenuated SCOP-induced memory impairments by different mechanisms. White ginseng extract inhibited $\mathrm{AChE}$ activity, leading to greater binding of ACh to the postsyn-
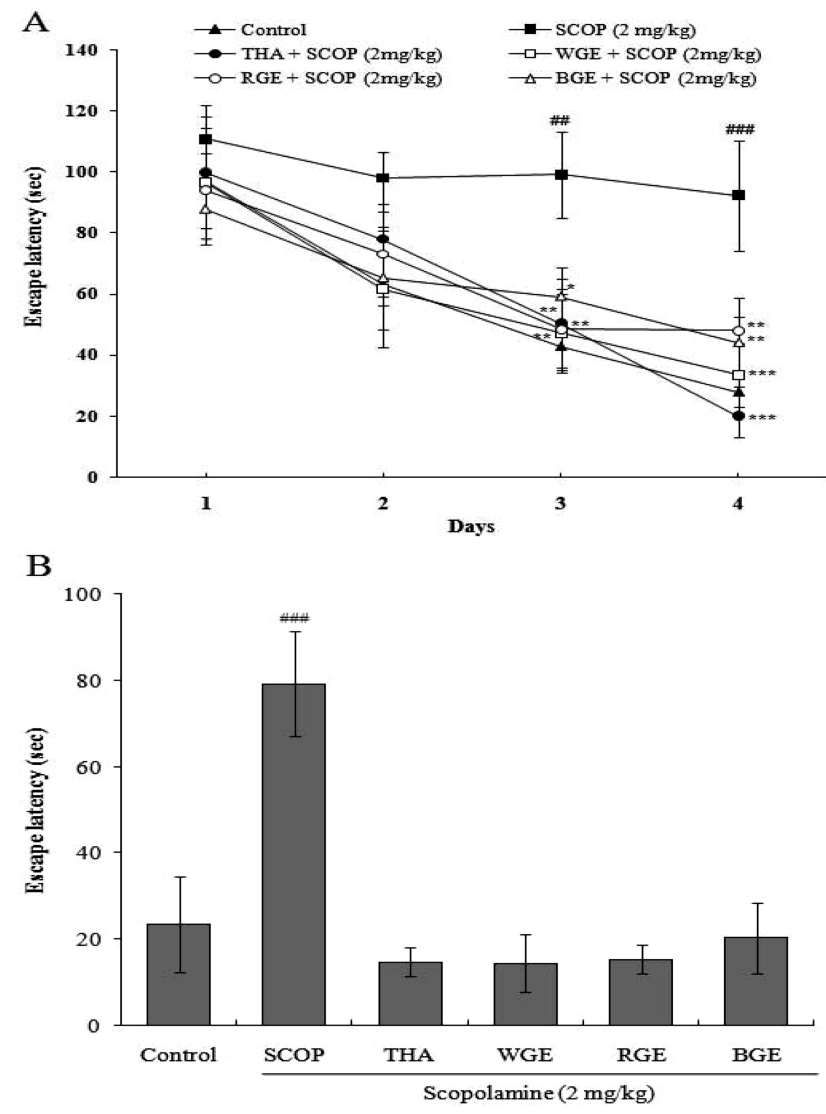

Fig. 3. Effect of Korean ginseng extracts on escape latency in the training-trial sessions following SCOP treatment (A) Training sessions for 4 days. (B) The probe trial session on day 5. Control (equal volume of $0.9 \%$ saline), THA (tacrine, $10 \mathrm{mg} / \mathrm{kg}$, p.o.), WGE, RGE, or BGE (white, red, and black ginseng extract, $200 \mathrm{mg} / \mathrm{kg}$, p.o., respectively) were administered to mice $60 \mathrm{~min}$ before the test. Memory impairment was induced by SCOP treatment (scopolamine, $2 \mathrm{mg} / \mathrm{kg}$, i.p.). The training trials were carried out $30 \mathrm{~min}$ after SCOP administration. Results are expressed as means $\pm \mathrm{SD}(\mathrm{n}=10) . * p<0.05, * * p<0.01$,

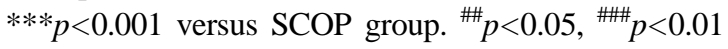
versus control group.

aptic ACh receptor, whereas black ginseng stimulated presynaptic ACh synthesis, leading to greater ACh release. Red ginseng extract appears to both increase ACh synthesis and inhibit ACh degradation, which would greatly increase synaptic ACh levels and most potently reverse SCOP-induced amnesia.

\section{Antioxidant effects of ginseng extracts}

We also measured the effects of ginseng extract treatment on antioxidant enzyme activity and lipid peroxide levels in mouse brain (Table 3). MDA is a reactive oxy- 
Table 2. Effect of Korean ginseng extracts on AChE and ChAT activity in mouse brain following SCOP treatment

\begin{tabular}{ccc}
\hline \hline Group $^{1)}$ & AChE & ChAT \\
\cline { 2 - 3 } & & U/mg protein/min \\
\hline Control & $8.78 \pm 1.04^{\mathrm{a}, \mathrm{b}^{2}}$ & $1.75 \pm 0.13^{\mathrm{b}}$ \\
SCOP & $9.04 \pm 1.03^{\mathrm{a}}$ & $1.70 \pm 0.03^{\mathrm{b}}$ \\
THA + SCOP & $7.72 \pm 0.38^{\mathrm{b}}$ & $1.76 \pm 0.08^{\mathrm{b}}$ \\
WGE + SCOP & $5.18 \pm 0.85^{\mathrm{c} * * *^{3)}}$ & $1.77 \pm 0.13^{\mathrm{b}}$ \\
RGE + SCOP & $5.69 \pm 0.85^{\mathrm{c} * * *}$ & $1.96 \pm 0.13^{\mathrm{a}}$ \\
BGE + SCOP & $8.63 \pm 0.48^{\mathrm{ab}}$ & $2.02 \pm 0.18^{\mathrm{a}}$ \\
\hline
\end{tabular}

${ }^{1)}$ Control: vehicle-treated group; SCOP: scopolamine $(2 \mathrm{mg} / \mathrm{kg}$, i.p. $)$ administered alone $30 \mathrm{~min}$ before Morris water maze test; THA: pretreated with tacrine $(10 \mathrm{mg} / \mathrm{kg}$, p.o. $)+$ scopolamine $30 \mathrm{~min}$ before Morris water maze test; WGE, RGE, and BGE: pretreated with each ginseng extract $(200 \mathrm{mg} / \mathrm{kg}$, p.o. $)+$ scopolamine $30 \mathrm{~min}$ before Morris water maze test. Values are expressed as means \pm SD of 10 animals in each group.

${ }^{2)}$ Values with different superscripts within the same row are significantly different at $p<0.05$.

3)** $p<0.01, * * * p<0.001$ versus SCOP group.

Table 3. Effect of ginseng extracts on antioxidant enzyme activity following SCOP treatment

\begin{tabular}{|c|c|c|c|c|}
\hline \multirow{2}{*}{ Groups $^{1)}$} & SOD & CAT & TAOC & \multirow{2}{*}{$\begin{array}{c}\text { MDA } \\
\text { (nmole/mg protein) }\end{array}$} \\
\hline & & (Unit/mg protein) & & \\
\hline Control & $65.49 \pm 4.15^{\mathrm{b}^{2)}}$ & $2.09 \pm 0.99^{\mathrm{a}}$ & $9.86 \pm 2.00^{\mathrm{ab}}$ & $7.44 \pm 1.27^{\mathrm{b}}$ \\
\hline SCOP & $88.23 \pm 10.95^{\mathrm{a}}$ & $1.34 \pm 0.29^{\mathrm{b}}$ & $6.93 \pm 0.95^{\mathrm{c}}$ & $11.96 \pm 2.31^{\mathrm{a} \# \#^{3)}}$ \\
\hline $\mathrm{THA}+\mathrm{SCOP}$ & $64.35 \pm 9.30^{\mathrm{b} * *^{3)}}$ & $1.32 \pm 0.21^{\mathrm{b}}$ & $9.04 \pm 0.89^{\mathrm{ab}}$ & $7.96 \pm 0.41^{\mathrm{b}}$ \\
\hline $\mathrm{WGE}+\mathrm{SCOP}$ & $64.86 \pm 9.27^{\mathrm{b} * *}$ & $1.63 \pm 0.23^{\mathrm{ab}}$ & $8.20 \pm 1.13^{b c}$ & $8.35 \pm 0.91^{\mathrm{b}}$ \\
\hline $\mathrm{RGE}+\mathrm{SCOP}$ & $71.38 \pm 16.19^{\mathrm{b}}$ & $1.80 \pm 0.35^{\mathrm{ab}}$ & $8.43 \pm 0.99^{\mathrm{bc}}$ & $7.71 \pm 2.20^{\mathrm{b}}$ \\
\hline $\mathrm{BGE}+\mathrm{SCOP}$ & $69.39 \pm 11.66^{\mathrm{b}}$ & $2.10 \pm 0.32^{\mathrm{a}}$ & $10.55 \pm 1.33^{\mathrm{a}}$ & $8.04 \pm 0.90^{\mathrm{b}}$ \\
\hline
\end{tabular}

${ }^{1)}$ Control: vehicle-treated group; SCOP: scopolamine $(2 \mathrm{mg} / \mathrm{kg}$, i.p. $)$ administered alone $30 \mathrm{~min}$ before Morris water maze test; THA: pretreated with tacrine $(10 \mathrm{mg} / \mathrm{kg}$, p.o. $)+$ scopolamine 30 min before Morris water maze test; WGE, RGE, and BGE: pretreated with each ginseng extract $(200 \mathrm{mg} / \mathrm{kg}$, p.o.) + scopolamine $30 \mathrm{~min}$ before Morris water maze test. Values are expressed as means \pm SD of 10 animals in each group.

${ }^{2)}$ Values with different superscripts within the same row are significantly different at $p<0.05$.

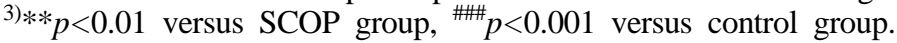

gen species (ROS) used as a biomarker for lipid peroxidation [22]. The amount of MDA in the SCOP group was $11.96 \pm 2.31 \mathrm{nmole} / \mathrm{mg}$ protein, which was $160 \%$ higher than that in the control group $(p<0.001)$. THA and ginseng extract treatment reduced lipid peroxidation to control levels. TAOC in the SCOP group was $6.93 \pm 0.95 \mathrm{U} /$ $\mathrm{mg}$ protein, which was significantly lower than that in the control group $(9.86 \pm 2.00 \mathrm{U} / \mathrm{mg}$ protein; $p<0.05)$. White and red ginseng treatment increased TAOC compared to the SCOP group but these changes were not significant with respect to controls. By contrast, black ginseng treatment produced the greatest increase in TAOC $(p<0.05)$. SOD, which removes the superoxide free radical, showed significantly elevated activity in the SCOP-treated group. This finding was consistent with a previous study using an animal model of Alzheimer's disease $(3 \times \mathrm{Tg}-\mathrm{AD}$ and PS1 mice), which found increased SOD activity in brain tissue, suggesting increased levels of oxidative stress [23].
CAT is an enzyme responsible for hydrogen peroxide degradation and showed significantly decreased activity in the SCOP group $(p<0.05)$, consistent with a previous study of brain tissue in dementia patients by Marcus et al. [24]. Conversely, ginseng extract treatment increased CAT activity, with black ginseng treatment producing the greatest increase. These data were in line with previous reports suggesting that ginseng extracts have substantial antioxidant activity [25-27]. The antioxidant activity of black ginseng in particular may be due to hydroxyl radical removal by black ginseng-specific ginsenosides including $\mathrm{Rg}_{3}, \mathrm{Rk}_{1}$, and $\mathrm{Rg}_{5}$ [28], in addition to the anti-cytotoxic activity of $\mathrm{Rg}_{3}$ [29] and neuroprotective effects of $\mathrm{Rg}_{3}$ after cerebral ischemia [30].

\section{ACKNOWLEDGEMENT}

This study was supported by Technology Development 
Program for Agriculture and Forestry (TDPAF), Ministry of Agriculture and Forestry, Republic of Korea (109159-2).

\section{REFERENCES}

1. Fodale V, Quattrone D, Trecroci C, Caminit V, Santamaria LB. Alzheimer's disease and anaesthesia : implications for the central cholinergic system. Br J Anaesth. 97: 445-452 (2006)

2. Bierer LM, Haroutunian V, Gabriel S, Knott PJ, Carlin LS, Purohit DP, Perl DP, Schmeidler J, Kanof P, Davis KL. Neurochemical correlates of dementia severity in Alzheimer's disease: relative importance of the cholinergic deficits. $\mathrm{J}$ Neurochem. 64: 749-76 (1995)

3. Bartus RT. On neurodegenerative diseases, models, and treatment strategies: lessons learned and lessons forgotten a generation following the cholinergic hypothesis. Exp Neurol. 163: 495-529 (2000)

4. Yamada N, Hattori A, Hayashi T, Nishikawa T, Fukuda H, Fujino $\mathrm{T}$. Improvement of scopolamine-induced memory impairment by Z-ajoene in the water maze in mice. Pharmacol Biochem Behav. 78: 787-791 (2004)

5. Shin HR, Kim JY, Yun TK, Morgan G, Vainio H. The cancerpreventive potential of Panax ginseng : a review of human and experimental evidence. Cancer Causes Control. 11: 565-576 (2000)

6. Attele AS, Wu JA, Yuan CS. Ginseng pharmacology : multiple constituents and multiple actions. Biochem Pharmacol. 58: 1685-1693 (1999)

7. Tian JW, Fu FH, Geng MY, Jiang YT, Yang JX, Jiang WL, Wang CY, Liu K. Neuroprotective effect of 20(S)-ginsenoside $\mathrm{Rg}_{3}$ on cerebral ischemia in rats. Neurosci Lett. 374: 9297 (2005)

8. Joo SS, Won TJ, Kim MS, Lee DI. Hematopoietic effect of ginsenoside $\mathrm{Rg}_{3}$ in ICR mouse primary cultures and its application to a biological response modifier. Fitoterapia 75: 337-341 (2004)

9. Yue PY, Wong DY, Wn PY, Leung PY, Liu L, Cai Z, Jian ZH, Fan TP, Wong RN. The angiosuppressive effects of 20(R)ginsenoside $\mathrm{Rg}_{3}$. Biochem Pharmacol. 72: 437-445 (2003)

10. Shi W, Wang YT, Li J, Zhang HQ, Ding L. Investigation of ginsenosides in different parts and ages of Panax ginseng. Food Chem. 102: 664-668 (2007)

11. Qiaoa CX, Denb R, Kudoa K, Yamada K, Takemotoc K, Watia H, Kanbad S. Ginseng enhances contextual fear conditioning and neurogenesis in rats. Neurosci Res. 51: 31-38 (2005)

12. Lee SC, Moon YS, You KH. Effects of red ginseng saponins and nootropic drugs on impaired acquisition of ethanoltreated rats in passive avoidance performance. J Ethnopharmacol. 69: 1-8 (2000)
13. Morris RG. Development of a water maze procedure for studying spatial learning in the rat. J Neurosic Meth. 11: 4760 (1984)

14. Ellman GL, Courtney KD, Andres JrV, Feather-Stone RM. A new and rapid colormetric determination of acetylcholinesterase activity. Biochem Pharmacol. 7: 88-95 (1961)

15. Uchiyama M, Mihara M. Determination of malonaldehyde precursor in tissues by thiobarbituric acid. Anal Biochem. 86: 271-278 (1978)

16. Bradford MM. A rapid and sensitive method for the quantitation of microgram quantities of protein utilizing the principle of protein-dye binding. Anal Biochem. 2: 248-254 (1976)

17. Han BH, Park MH, Han YN, Woo LK. Sankawa U, Tanaka O. Degradation of ginseng saponins under mild acidic conditions. Planta Med. 44: 146-149 (1982)

18. Troster AI, Beatty WW, Staton RD, Rorabaugh AG. Effect of scopolamine on anterograde and remote memory in humans. Psychobiology 17: 12-18 (1989)

19. Ballard CG, Greig NH, Guillozet-Bongaarts AL. Cholinesterases: roles in the brain during health and disease. Curr Alzheimer Res. 2: 307-318 (2005)

20. Yamada N, Hattori A, Hayashi T, Nishikawa T, Fukuda H, Fujino T. Improvement of scopolamine-induced memory impairment by Z-ajoene in the water maze in mice. Pharmacol Biochem Behav. 78 : 787-791 (2004)

21. Jackson JJ, Soliman MRI. Effects of tacrine (THA) on spatial reference memory and cholinergic enzymes in specific rat brain regions. Life Sci. 58: 47-54 (1995)

22. Bassett CN, Montine TJ. Lipoproteins and lipid peroxidation in Alzhimer's disease. J Nutr Health Aging 7: 446-451 (2003)

23. Resende R, Moreira PI, Proença T, Deshpande A, Busciglio J, Pereira C, Oliveria CR. Brain oxidative stress in a tripletransgenic mouse model of Alzheimer disease. Free Radic Biol Med. 44: 2051-2057 (2008)

24. Marcus DL, Thomas C, Rodriguez C, Simberkoff K, Tsai JS, Strafaci JA, Freedman ML. Increased peroxidation and reduced antioxidant enzyme activity in Alzheimer's disease. Exp Neurol. 150: 40-44 (1998)

25. Keum YS, Park KK, Lee JM, Chun KS, Park JH, Lee SK, Kwon HJ, Surh YJ. Antioxidant and anti-tumor promoting activities of the methanol extract of heat-processed ginseng. Cancer Lett. 150: 41-48 (2000)

26. Chen R, Meng F, Zhang S, Liu Z. Effects of ultrahigh pressure extraction conditions on yields and antioxidant activity of ginsenoside from ginseng. Sep Purif Technol. 66: 340-346 (2009)

27. Lee SR, Kim MR, Yon JM, Baek IJ, Park CC, Lee BJ, Yun YW, Nam SY. Black ginseng inhibits ethanol-induced teratogenesis in cultured mouse embryos through its effects on antioxidant activity. Toxicol Vitro. 23: 47-52 (2009)

28. Kang KS, Kim HY, Yamabe N, Yokosawa T. Stereospecific- 
ity in hydroxyl radical scavenging activities of four ginsenosides produced by heat processing. Bioorg Med Chem Lett. 16: 5028-5031 (2006)

29. Kim JH, Cho SY, Lee JH, Jeong SM, Yoon IS, Lee BH, Lee JH, Pyo MK, Lee SM, Chung JM, Kim O, Rhim HW, Oh JW, Nah SY. Neuroprotective effects of ginsenoside $\mathrm{Rg}_{3}$ against homocysteine-induced excitotoxicity in rat hippocampus. Brain Res.1136: 190-199 (2007)

30. Tian J, Fu F, Geng M, Jiang Y, Yang J, Jiang W, Wang C, Liu $\mathrm{K}$. Neuroprotective effect of $20(\mathrm{~S})$-ginsenoside $\mathrm{Rg}_{3}$ on cerebral ischemia in rats. Neurosci Lett. 374: 92-97 (2005) 